\title{
PLANT COMMUNITIES OF CULTIVATED FIELDS OF THE PODLASKI PRZEŁOM BUGU MESOREGION PART VI. COMMUNITIES OF ROOT CROPS ON COMPACT SOILS
}

\author{
Zofia Rzymowska \\ The Agricultural Ecology Department of the University of Podlasie in Siedlce, B. Prusa 14, 08-110 Siedlce, Poland, \\ e-mail: ekorol@ap.siedlce.pl
}

Received: 5.02.2010

\begin{abstract}
Analysis of plant communities accompanying root crops on compact soils is presented in the paper. It is the next part of the review of plant communities of agrocenoses of the Podlaski Przełom Bugu (Podlasie Bug Gorge) mesoregion. The studied phytocoenoses were identified on the basis of 103 phytosociological relevés, made according to the Braun-Blanquet method. In the studied agrocenoses, plots of the associations Lamio-Veronicetum politae, Galinsogo-Setarietum and Oxalido-Chenopodietum polyspermi from the Polygono-Chenopodion polyspermi alliance were noted. Small patches of Lamio-Veronicetum and Oxalido-Chenopodietum were rarely noted in the studied area due to a small proportion of suitable habitats. In the area of Podlaski Przełom Bugu mesoregion, phytocoenoses of Oxalido-Chenopodietum developed in the river valleys on fertile muds and black soils. Typical plots of Galinsogo-Setarietum distinguishable by the mass occurrence of Galinsoga parviflora were only observed in the vicinity of farm buildings. Intermediate communities between PanicoSetarion and Polygono-Chenopodion polyspermi as well as phytocoenoces of Echinochloo-Setarietum typicum - subvariant with Veronica persica and Echinochloo-Setarietum fumarietosum - were also quite frequently noted in root crops on compact soils.
\end{abstract}

Key words: cultivated fields, root crop communities, compact soils, Podlaski Przełom Bugu mesoregion

\section{INTRODUCTION}

The present paper is the next part of the review of plant communities of agrocenoses of the Podlaski Przełom Bugu mesoregion (S k r z y z y ń ska and Rzymowska, 2005; Rzymowska and Skrzy czyńska，2006a; 2006b; 2006c; 2007). It concerns the analysis of communities developing in root crops on compact soils. The characteristics of the agrocenoses were made on the basis of
103 phytosociological relevés. The methodical principles, e.g., the list of localities with their numbering and the characteristics of the study area, were published in a paper by Skrzyczyńska and Rzymowska (2005).

\section{RESULTS}

Systematics of the identified root crop communities:

Class: Stellarietea mediae R. Tx., Lohm. et Prsg, 1950

Order: Polygono-Chenopodietalia (R. Tx. et Lohm. 1950) J. Tx. 1961

Alliance: Panico-Setarion Siss. 1946

1. Association: Echinochloo-Setarietum Krus. et Vlieg. (1939) 1940

Subassociation: Echinochloo-Setarietum typicum

a. typical variant

- subvariant with Veronica persica

b. variant with Mentha arvensis

- subvariant with Veronica persica

Subassociation: Echinochloo-Setarietum fumarietosum

a. typical variant

b. variant with Stachys palustris

2. Intermediate community between Panico-Setarion and Polygono-Chenopodion polyspermi

a. typical form

b. form with participation of hygrophilous species

Alliance: Polygono-Chenopodion Siss. 1946

3. Association: Lamio-Veronicetum politae Kornaś 1950

a. typical variant

b. variant with Mentha arvensis

4. Association: Oxalido-Chenopodietum polyspermi Siss. 1950

5. Association: Galinsogo-Setarietum (R. Tx. et Beck. 1942) R. Tx. 1950 
Phytocoenoses developing on compact soils in root crops in the area of the Podlaski Przełom Bugu mesoregion were diverse and floristically rich. The studied crops were dominated by fertile forms of Echinochloo-Setarietum (Panico-Setarion alliance) and communities from the Polygono-Chenopodion alliance: Lamio-Veronicetum politae, Oxalido-Chenopodietum polyspermi and Galinsogo-Setarietum.

\section{Echinochloo-Setarietum typicum Krus. et Vlieg. (1939) 1940}

On compact soils, there were observed numerous plots of Echinochloo-Setarietum typicum - subvariant with Veronica persica and Echinochloo-Setarietum fumarietosum.

Plots of Echinochloo-Setarietum typicum with Veronica persica were usually noted on good wheat and very good rye soil complexes, developed from clay, light and strong clayey sands. They were identified on the basis of 20 phytosociological relevés (Table 1). Apart from the plants characteristic for the association, a numerous group of species from the Polygono-Chenopodion alliance and Polygono-Chenopodietalia order was recorded, of which Veronica persica was the most frequently noted. The species such as Lamium purpureum, Veronica agrestis, Galinsoga ciliata, Sonchus asper and Euphorbia helioscopia were less frequently observed. Moreover, a large share of nitrophilous plants from the class Stellarietea mediae, e.g., Stellaria media, Chenopodium album and Matricaria maritima ssp. inodora, was characteristic for this subvariant.

The variant with Mentha arvensis was distinguishable by the occurrence of species typical for excessively wet soil, e.g., Mentha arvensis, Gnaphalium uliginosum, Juncus bufonius, Stachys palustris, Potentilla anserina Plantago intermedia, Rorippa sylvestris.

In total, 99 species were noted in the analysed phytocoenoses (68 in typical plots and 88 in the variant with Mentha arvensis). Number of species in one relevé varied, respectively, from 14 to 29 (on average 21 ) and from 19 to 40 (on average 28).

\section{Echinochloo-Setarietum fumarietosum}

On the soils of very good and good rye, good wheat and strong cereal-fodder complexes, plots of Echinochloo-Setarietum fumarietosum developed. The subassociation was described on the basis of 20 phytosociological relevés (Table 2). The phytocoenoses were observed both on optimally and excessively wet soils, which was the reason for the division of the subassociation into two variants: typical and variant with Stachys palustris. In the typical and moist plots of the subassociation, a constant and large proportion of Echinochloa crus-galli was observed. Raphanus raphanistrum was noted more rarely and less abundantly. A frequent occurrence of Fumaria officinalis was also characteristic for the subassociation. Other characteristic species of Polygono-Chenopodion (also distinguishable ones) were less frequently and abundantly noted, especially in the plots of the variant with Stachys palustris. They were as follows: Euphorbia helioscopia, Neslia paniculata, Sonchus asper, Lamium purpureum, Lamium amplexicaule, Veronica persica. In typical plots, a significant proportion of $G a$ linsoga parviflora was observed. Moreover, in typical and moist plots, a mass occurrence of Chenopodium album and a slightly smaller proportion of Stellaria media were noted. The moist variant of the subassociation was distinguishable by a considerable share of hygrophilous species, e.g. Stachys palustris, Gnaphalium uliginosum, Mentha arvensis, Juncus bufonius, Rorippa sylvestris.

In total, 113 species were noted in the analysed phytocoenoses (79 in typical plots and 93 in plots with Stachys palustris). Number of species in one relevé varied, respectively, from 15 to 38 (on average 26) and from 20 to 45 (on average 31 ).

\section{The intermediate community between Panico-Setarion and Polygono-Chenopodion polyspermi}

In root crops of the Podlaski Przełom Bugu mesoregion, intermediate phytocoenoses with the participation of species characteristic for the alliances Panico-Setarion and Polygono-Chenopodion polysper$m i$ were also observed. Such plots were noted on various soil types, including rye (especially very good rye), wheat (especially good rye) and strong cereal-fodder complexes. The communities were identified on the basis of 20 phytosociological relevés (Table 3 ).

In these phytocoenoses, a numerous group of species characteristic for the Polygono-Chenopodion alliance was noted. Among them, there was observed a high proportion of Euphorbia helioscopia, Sonchus asper, Veronica persica and Galinsoga parviflora as well as Veronica agrestis in the typical variant. The characteristic species for Panico-Setarion were recorded less frequently and with little cover. The only exception was Echinochloa crus-galli occurring abundantly, especially in plots rich in hygrophilous species. A considerable proportion of plants with high nutrient demands testify to high habitat fertility. Apart from the species from the Polygono-Chenopodion polyspermi alliance, the following were found: Chenopodium album, Stellaria media, Anagallis arvensis, Capsella bursa-pastoris, Galium aparine and Polygonum lapathifolium ssp. lapathifolium. 
A form of community with the participation of hygrophilous species was identified on the basis of the occurrence of such species, as, Plantago intermedia, Gnaphalium uliginosum, Juncus bufonius, Ranunculus repens, Stachys palustris.

In total, 103 species were noted in the analysed phytocoenoses (72 in typical form and 88 in plots with the participation of hygrophilous species). Number of species in one relevé varied, respectively, from 20 to 33 (on average 24) and from 26 to 45 (on average 34 ).

\section{Lamio-Veronicetum politae Kornaś 1950}

Small plots of Lamio-Veronicetum politae were rarely observed, usually on soils of good and week wheat complexes and strong cereal-fodder complex. Diverse habitat conditions (especially soil moisture) are the reason for the division of the association into two variants: typical and variant with Mentha arvensis. The association was identified on the basis of 23 phytosociological relevés (13 - typical variant and 10 - moist variant) (Table 4).

Typical plots of Lamio-Veronicetum politae developed in potato and beet crops, on typical brown and black soils and muds of wheat soil complexes. The following species characteristic for the association: Veronica polita, Euphorbia helioscopia, Veronica opaca, Lamium amplexicaule and Sonchus asper, were recorded. From among the species characteristic for the alliance, the most frequently and abundantly were noted the following: Veronica agrestis, Veronica persica, Lamium purpureum, Galinsoga parviflora and Lapsana communis. Stellaria media, Chenopodium album, Capsella bursa-pastoris, Anagallis arvensis and Galium aparine were also recorded frequently and with high cover.

Plots with Mentha arvensis developed on clayey soils of good wheat and strong cereal-fodder soil complexes. These phytocoenoses were characterised by a high proportion of hygrophilous species, e.g. Mentha arvensis, Plantago intermedia, Stachys palustris, Potentilla anserina.

The associations were floristically rich. In total, 100 species were noted in them (80 in typical variant and 83 in variant with Mentha arvensis). Number of species in one relevé varied, respectively, from 19 to 31 (on average 23) and from 23 to 39 (on average $30)$.

\section{Oxalido-Chenopodietum polyspermi Siss. 1950}

Plots of the association Oxalido-Chenopodietum polyspermi were not frequently noted in root crops of the investigated area. They developed in beet and potato plantations, in the vicinity of watercourses. The association was usually observed on black soils and muds, classified as strong cereal-fodder complex. The association was distinguished on the basis of 10 phytosociological relevés (Table 5). The species characteristic for the association, Chenopodium polyspermum and Oxalis stricta, were a constant component of the phytocoenoses and had high cover. Numerous distinguishable plants, e.g. Plantago intermedia, Mentha arvensis, Galeopsis tetrahit and more rarely Symphytum officinale, were also recorded. Moreover, a numerous group of hygrophilous plants, e.g., Juncus bufonius, Gnaphalium uliginosum, Rorippa sylvestris, Polygonum amphibium, as well as other plants characteristic for PolygonoChenopodion polyspermi occurring in constancy classes III and II were observed in these phytocoenoses (quite often with a high degree of cover). A high proportion of nitrophilous plants, e.g. Stellaria media, Chenopodium album and Matricaria maritima ssp. inodora, was also characteristic for these communities. Echinochloa crus-galli and less frequently other species from the Panico-Setarion alliance were also a constant component of these phytocoenoses.

In total, the occurrence of 94 species was noted in the analysed plots of this association. Number of species in one relevé varied from 26 to 42 (on average 33).

\section{Galinsogo-Setarietum \\ (R. Tx. et Beck. 1942) R. Tx. 1950}

On various soils, classified as rye and wheat complexes, usually in the vicinity of farms, there were observed plots of the association GalinsogoSetarietum. The phytocoenoses were dominated by Galinsoga parviflora, whereas Galinsoga ciliata and Setaria pumila were noted less abundantly (Table 6). The proportion of other species characteristic for Polygono-Chenopodion was much lower, of which the most frequent and numerous was Veronica persica. Species such as, e.g. Veronica agrestis, Lamium purpureum, Euphorbia helioscopia, Sonchus asper, used to reach a lower degree of cover. Plots of the phytocoenoses with a mass occurrence of Stellaria media and Chenopodium album were also noted.

In spite of high weed cover, plots of Galinsogo-Setarietum were the floristically poorest phytocoenoses developing on compact soils of the study area. In total, 76 weed species were noted in them. Number of species in one relevé varied from 17 to 32 (on average 23). 


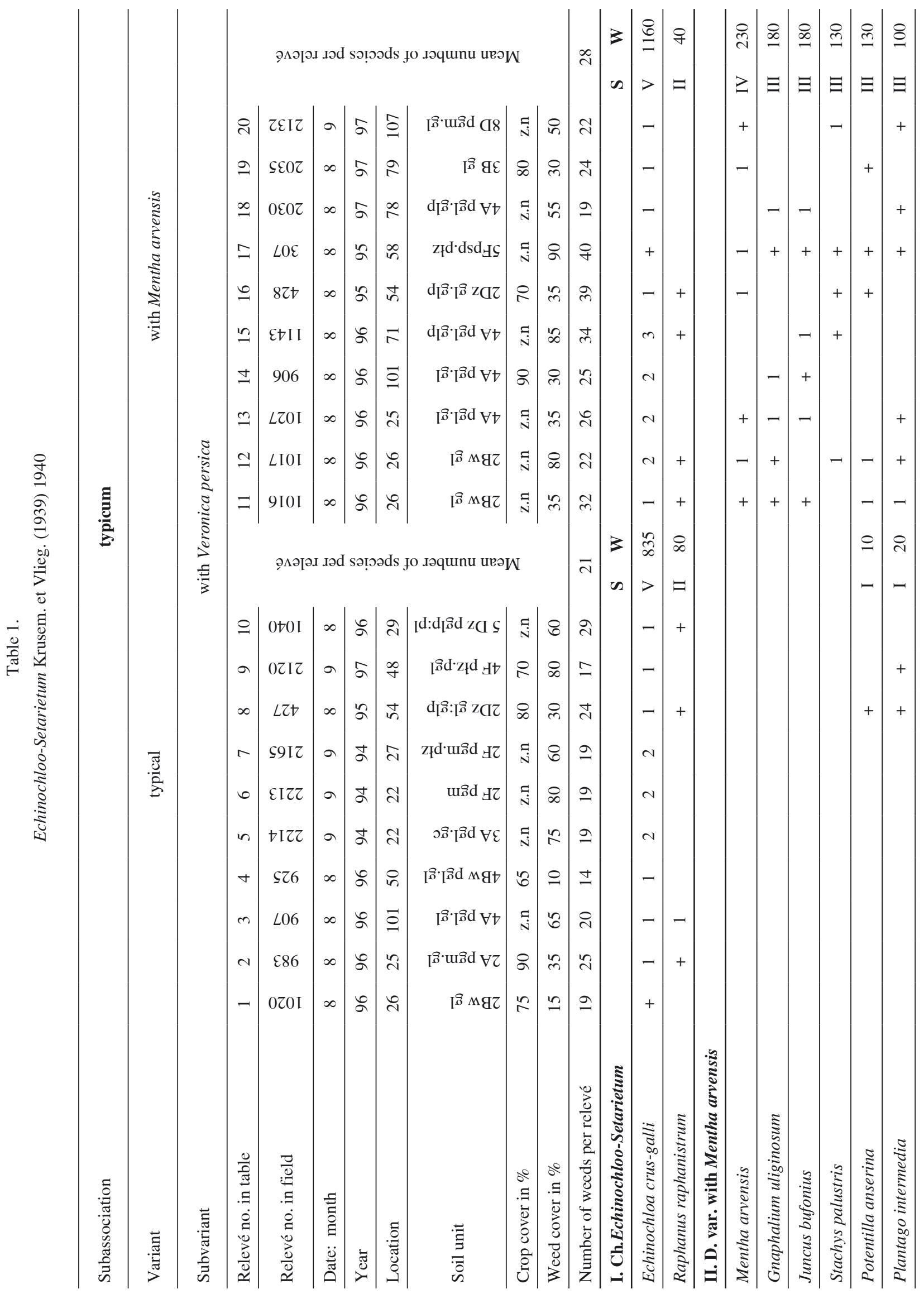




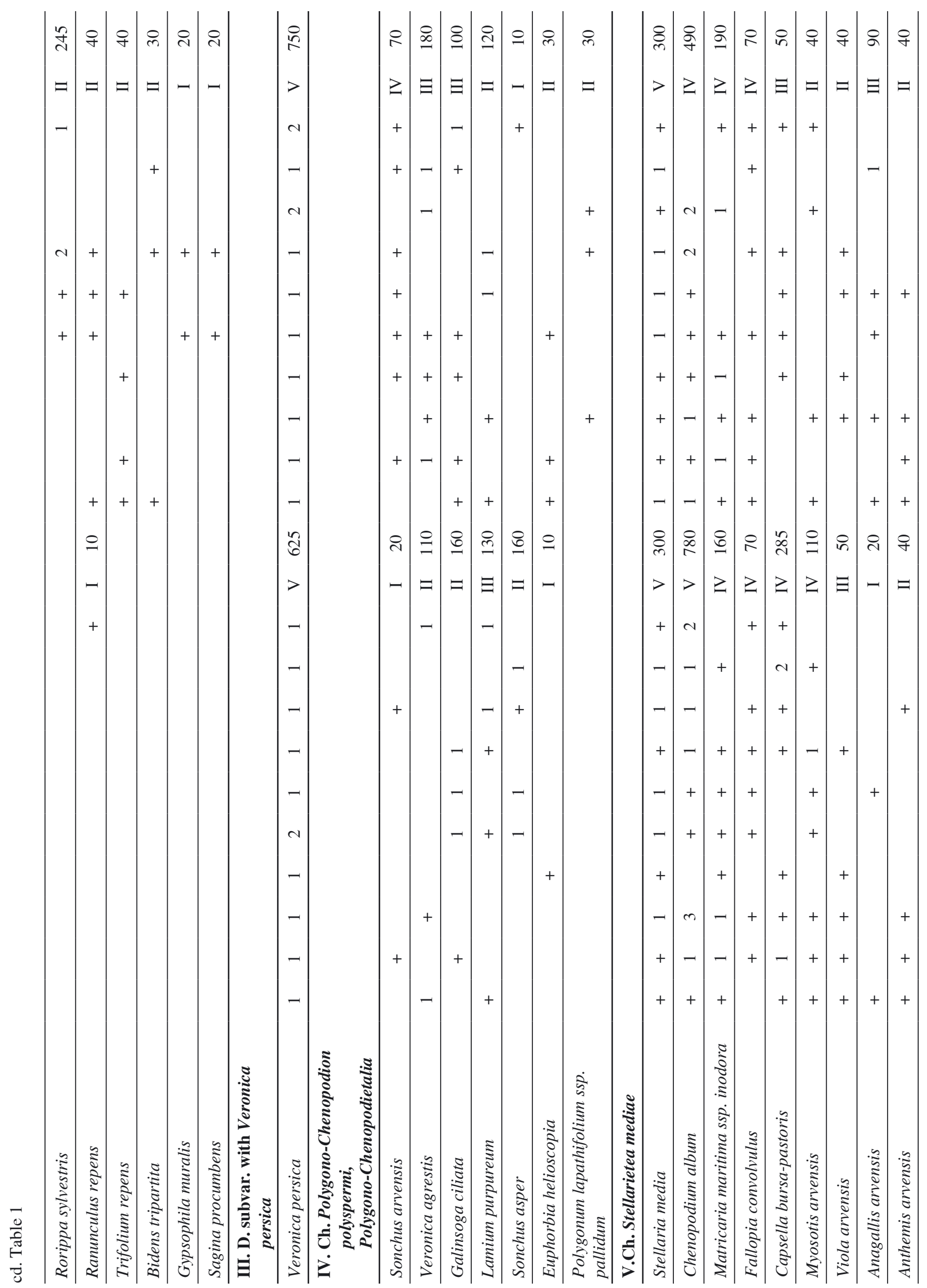




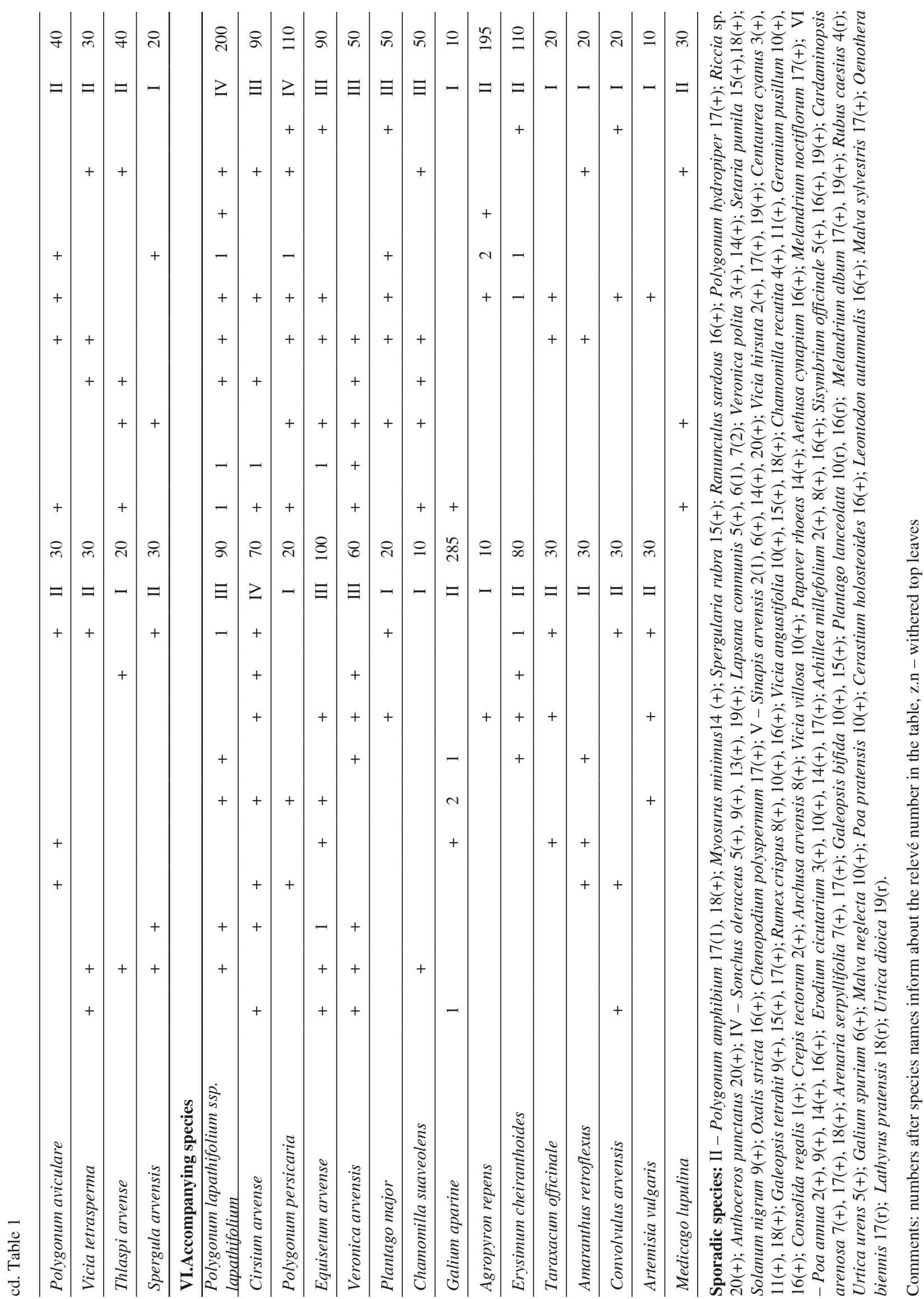




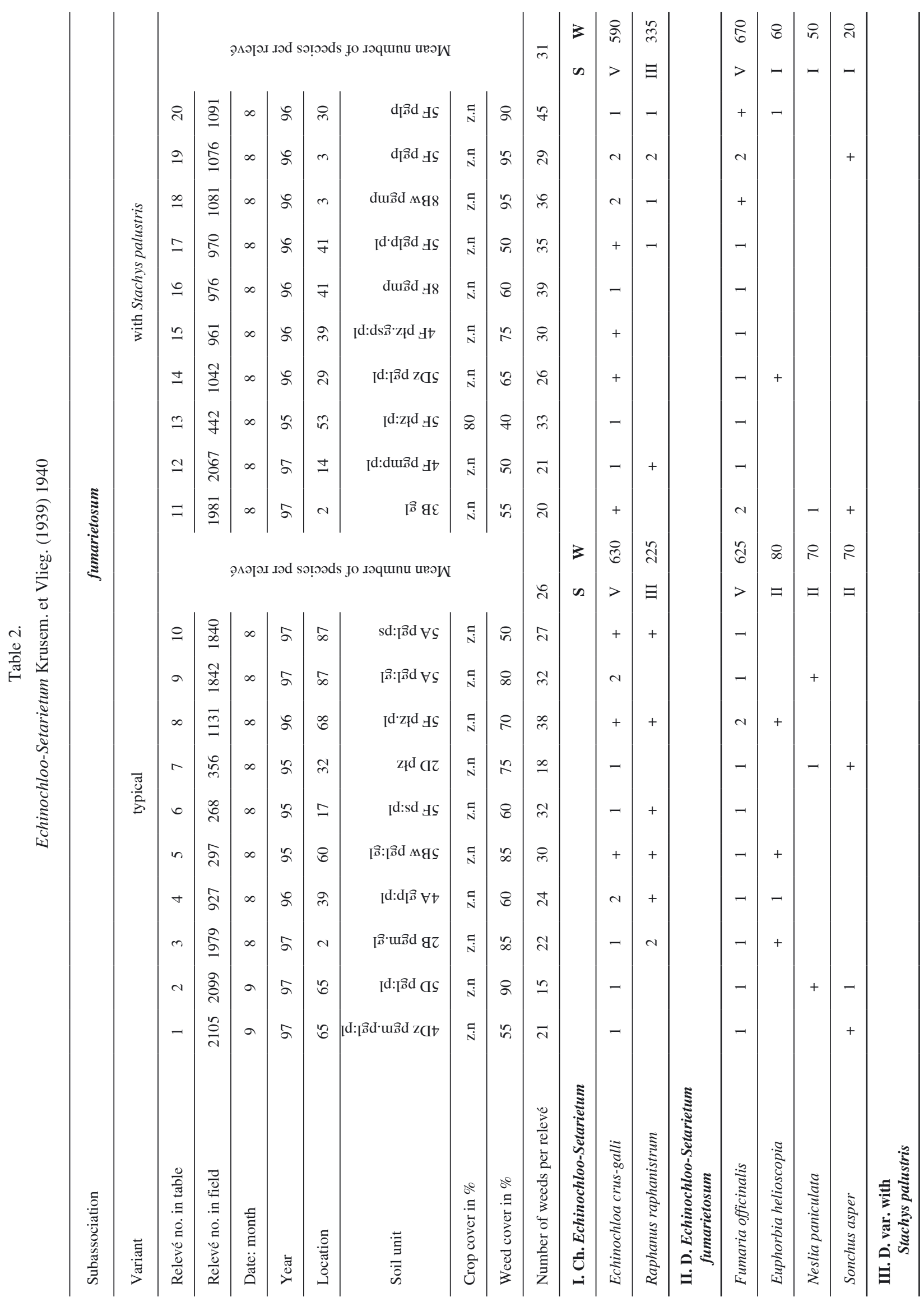




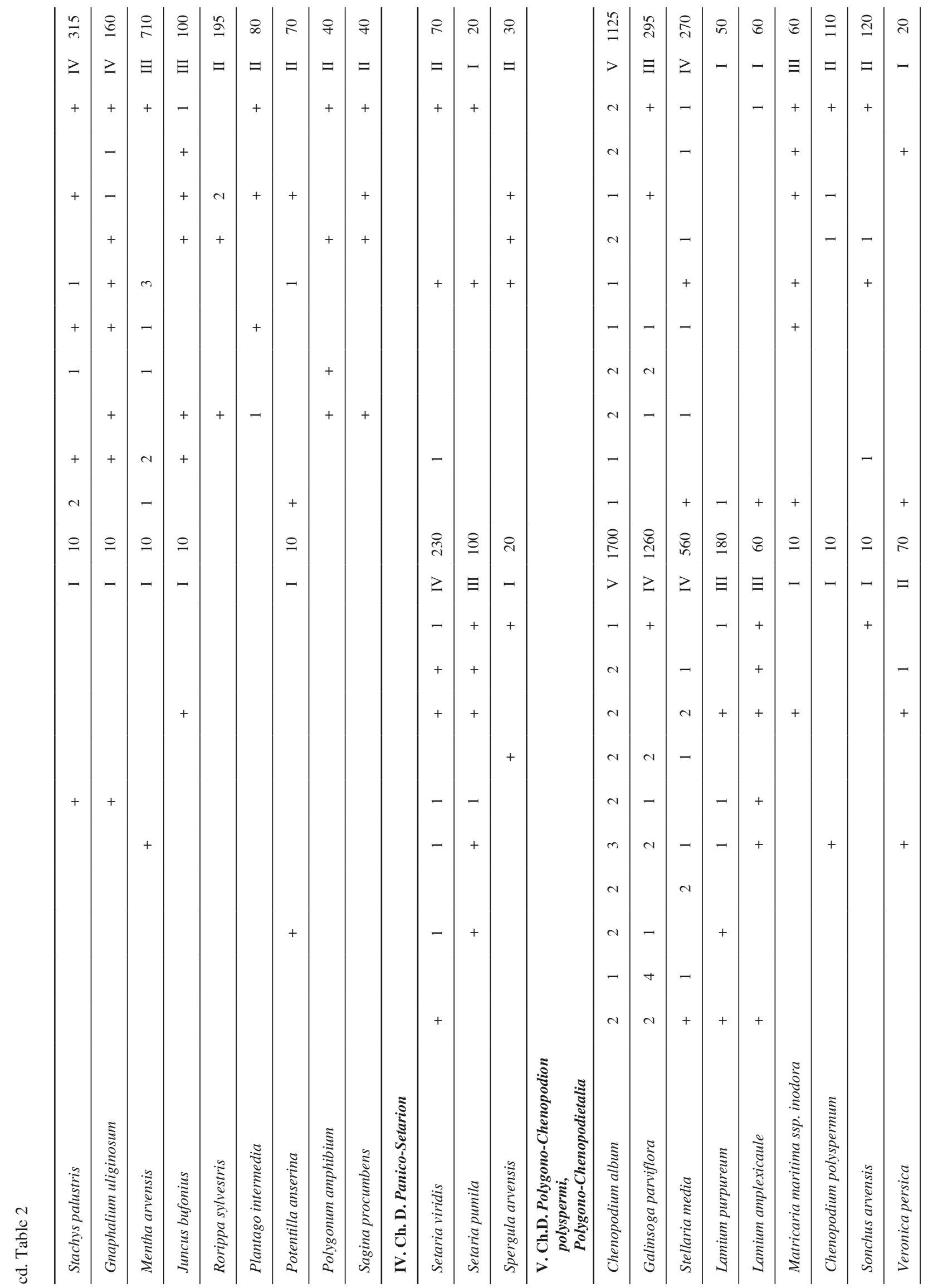




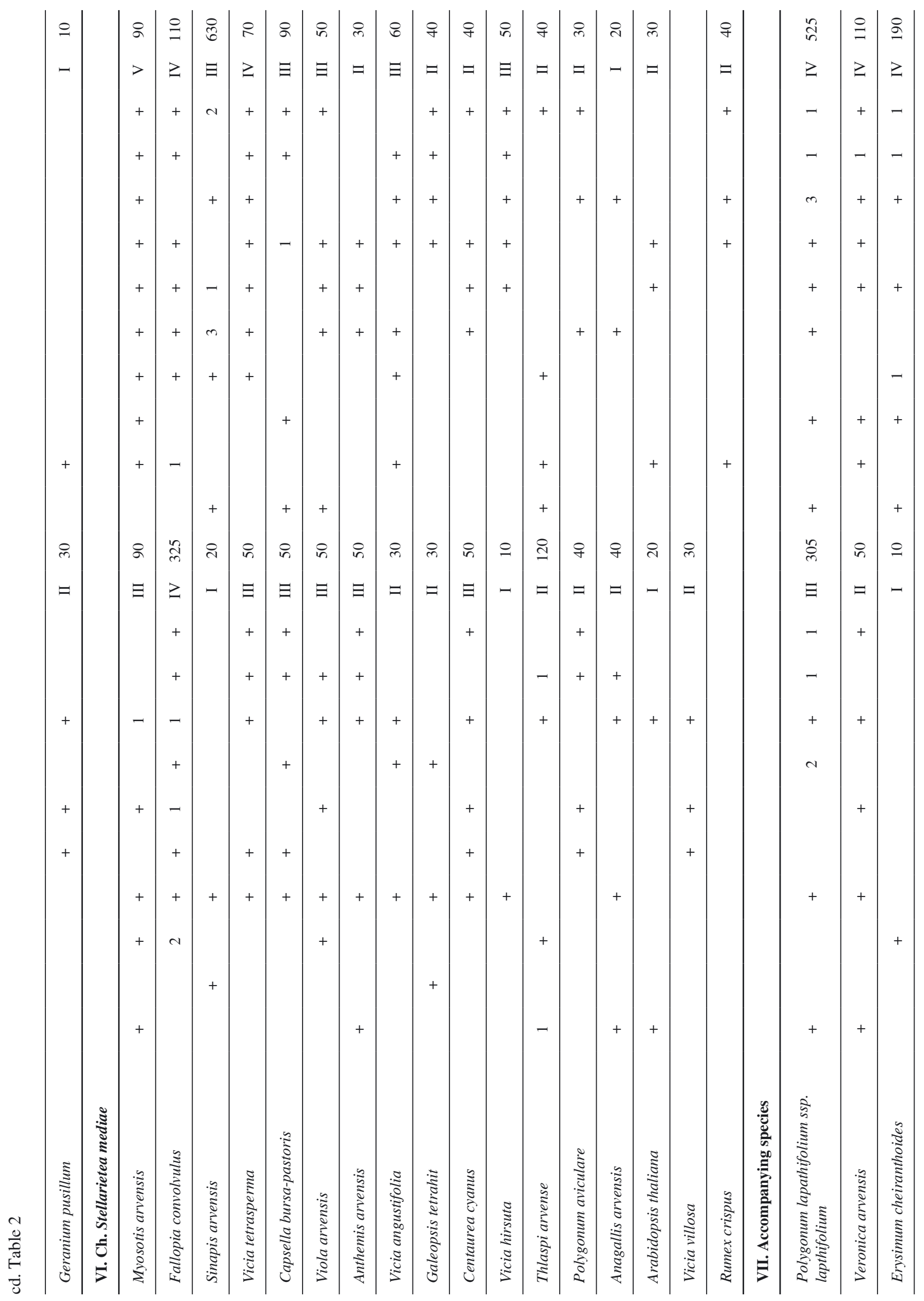




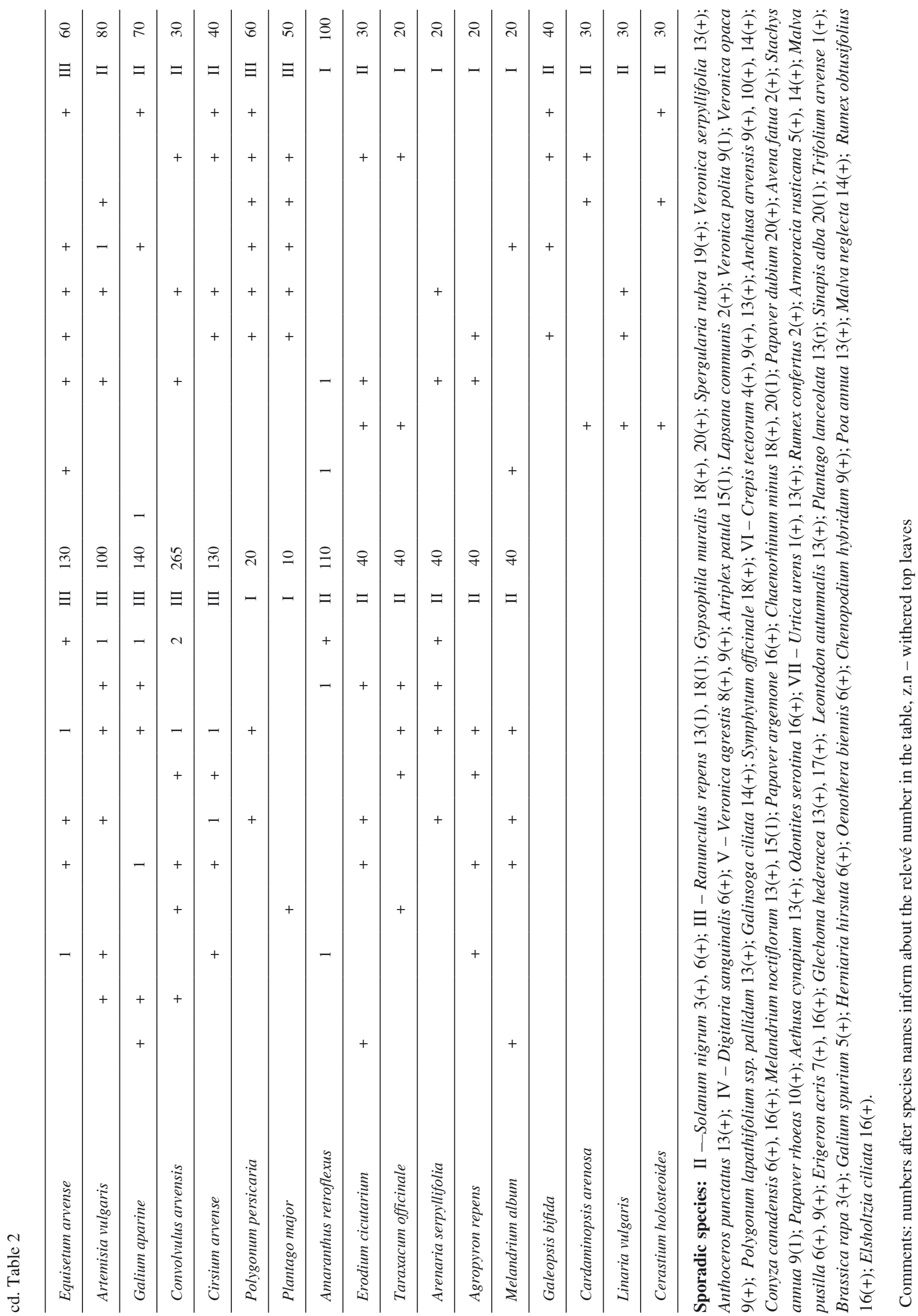




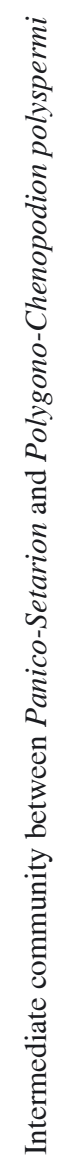

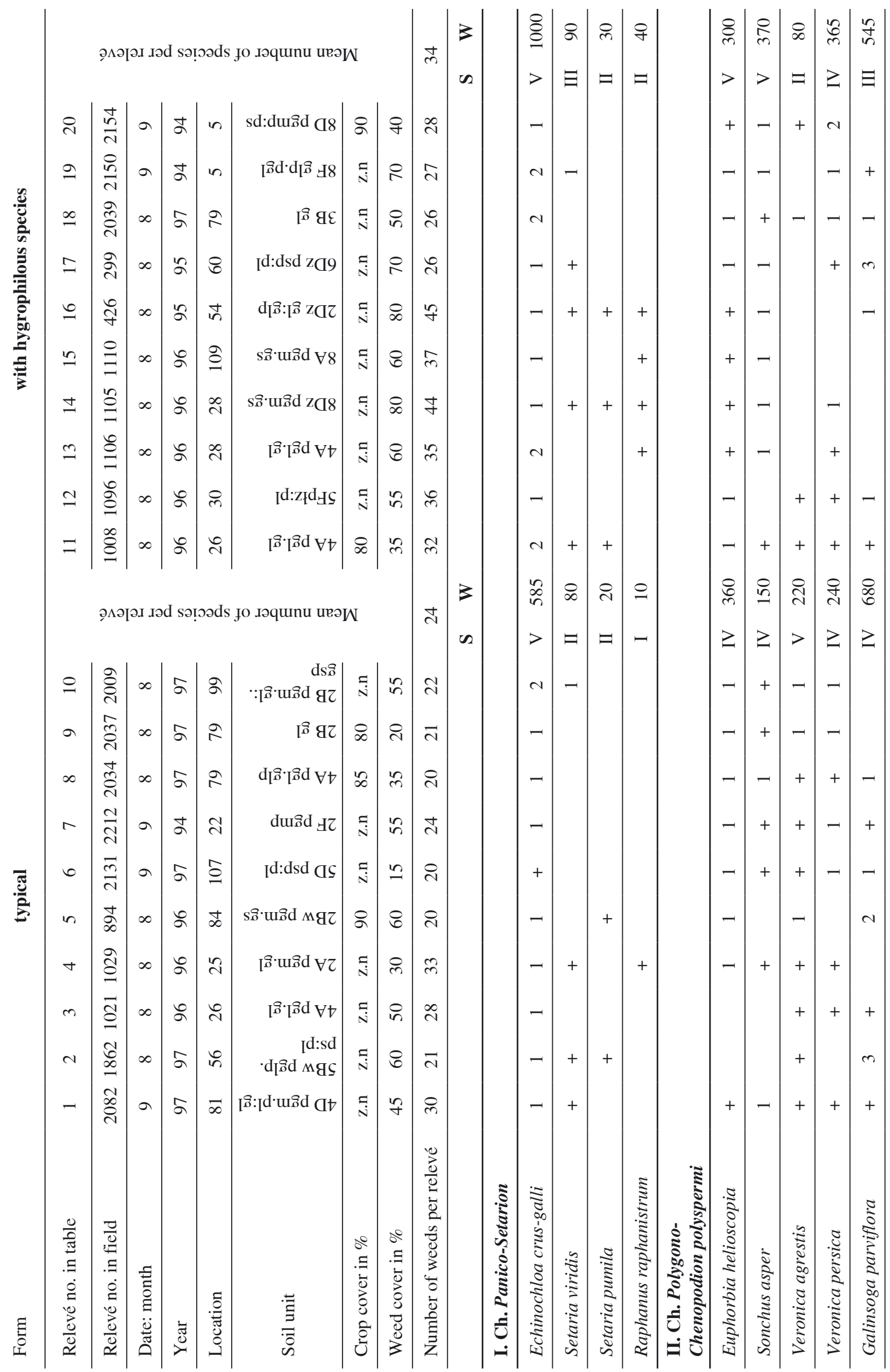




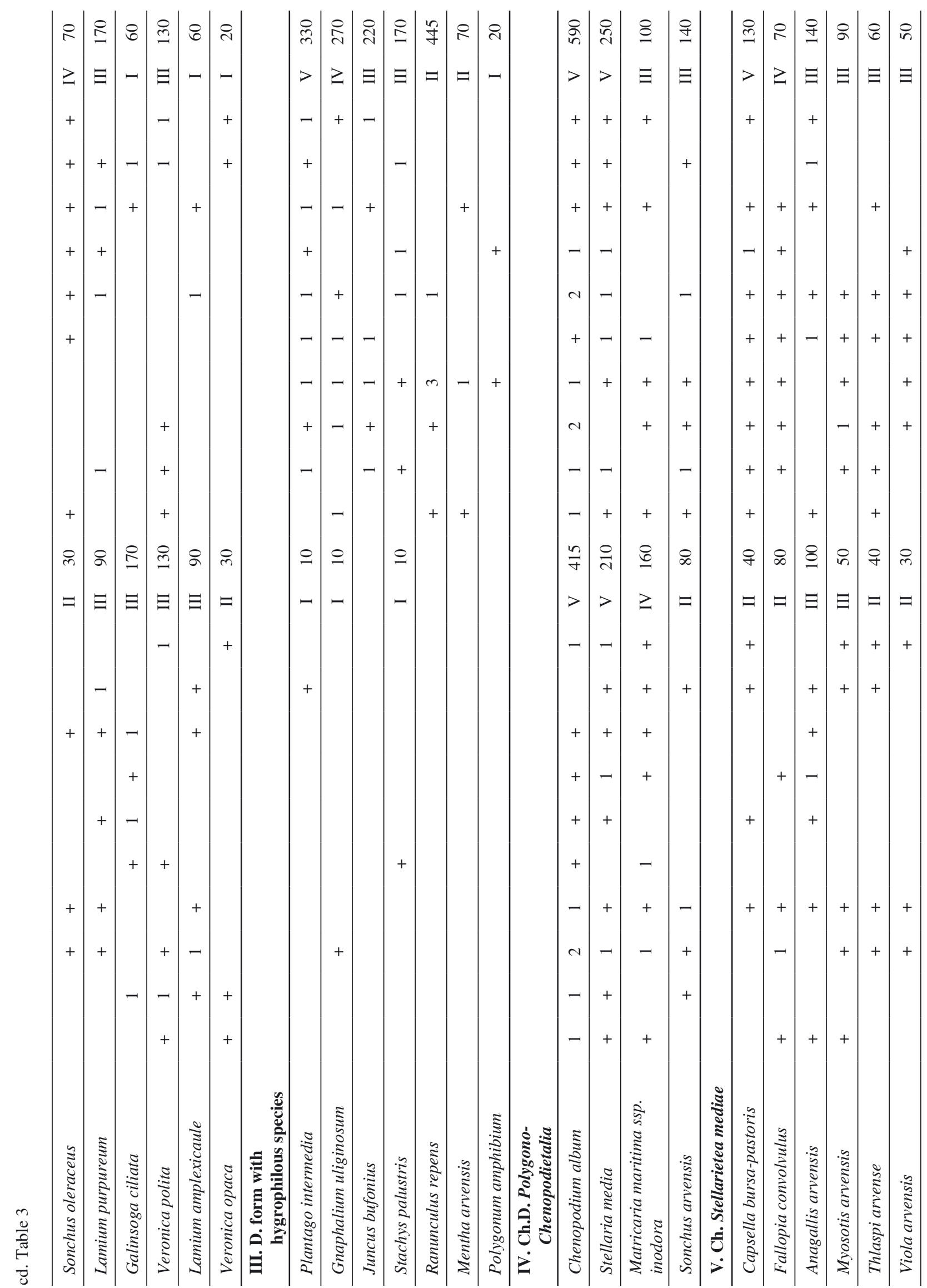




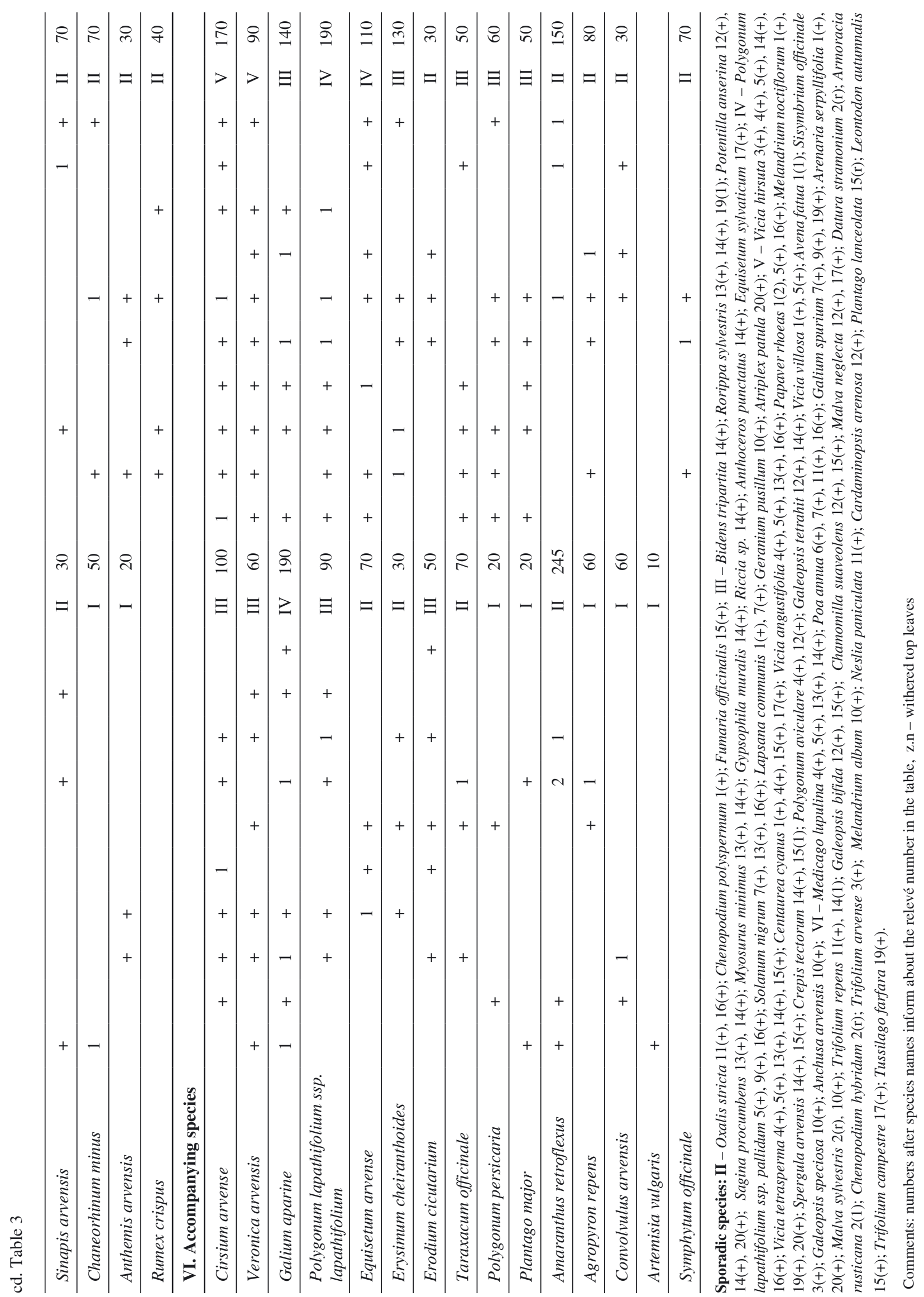




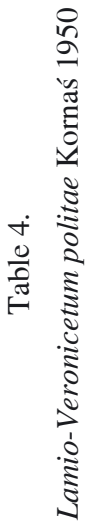

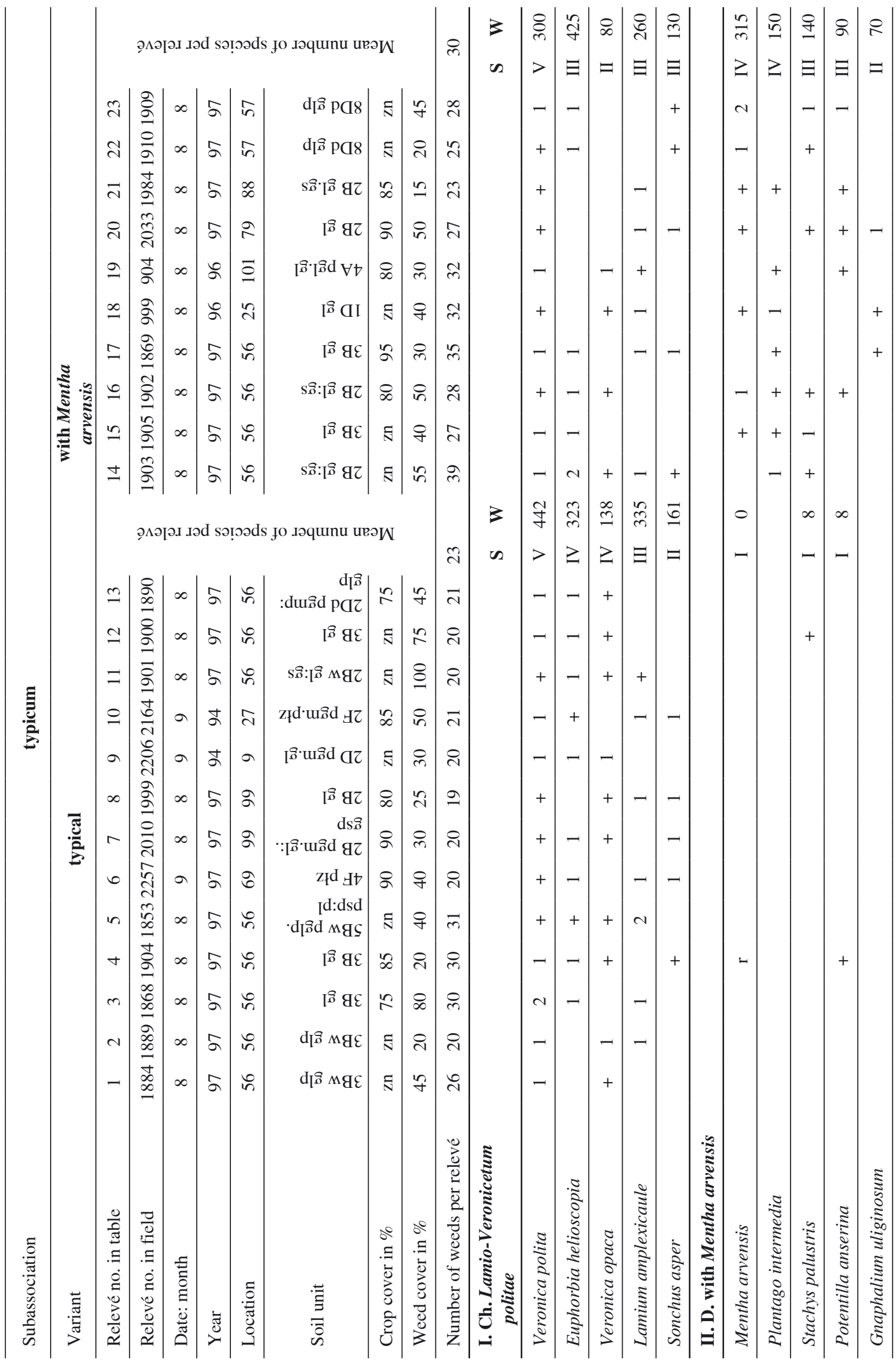




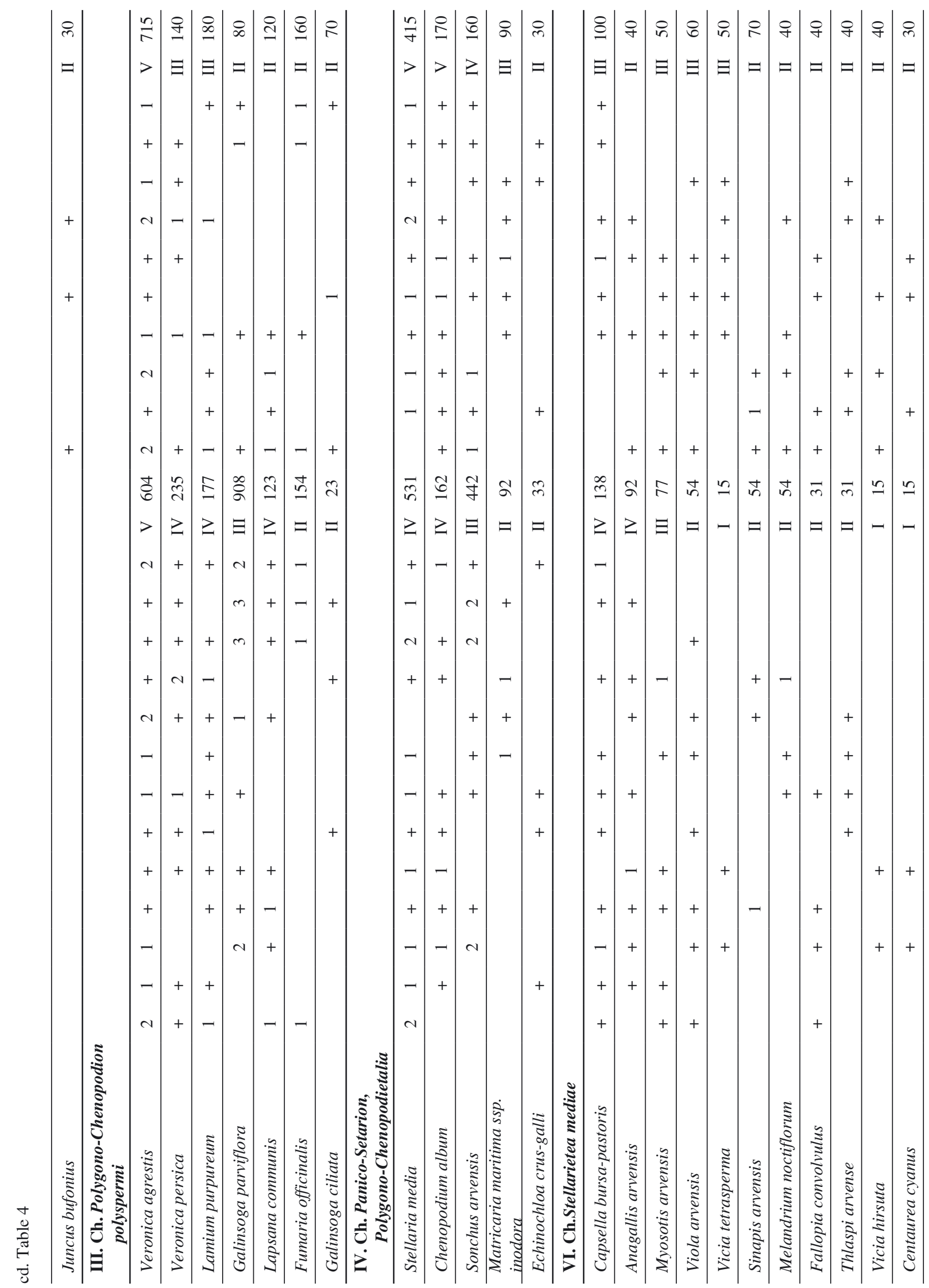




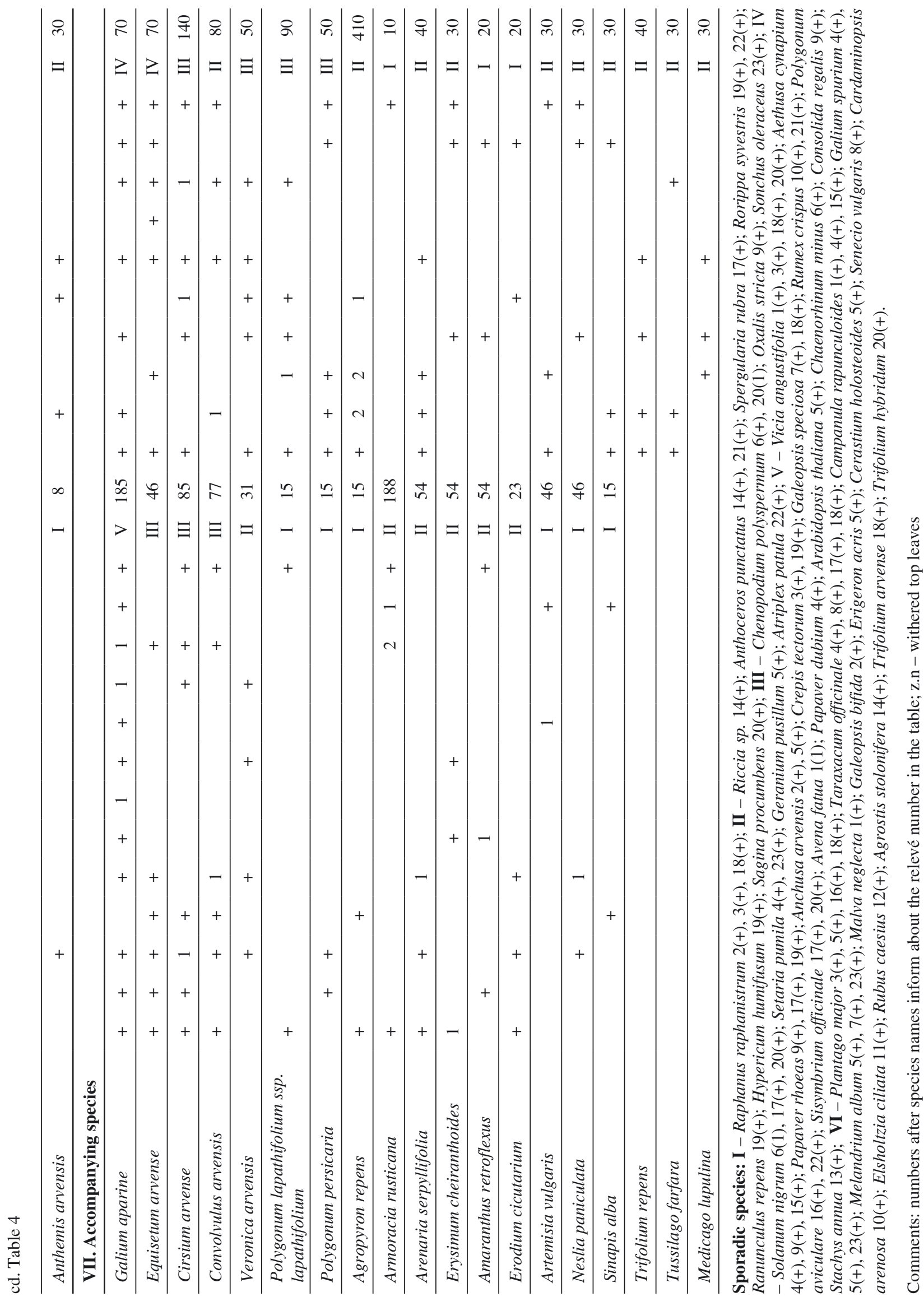


Table 5.

Oxalido-Chenopodietum polyspermi Siss. 1950

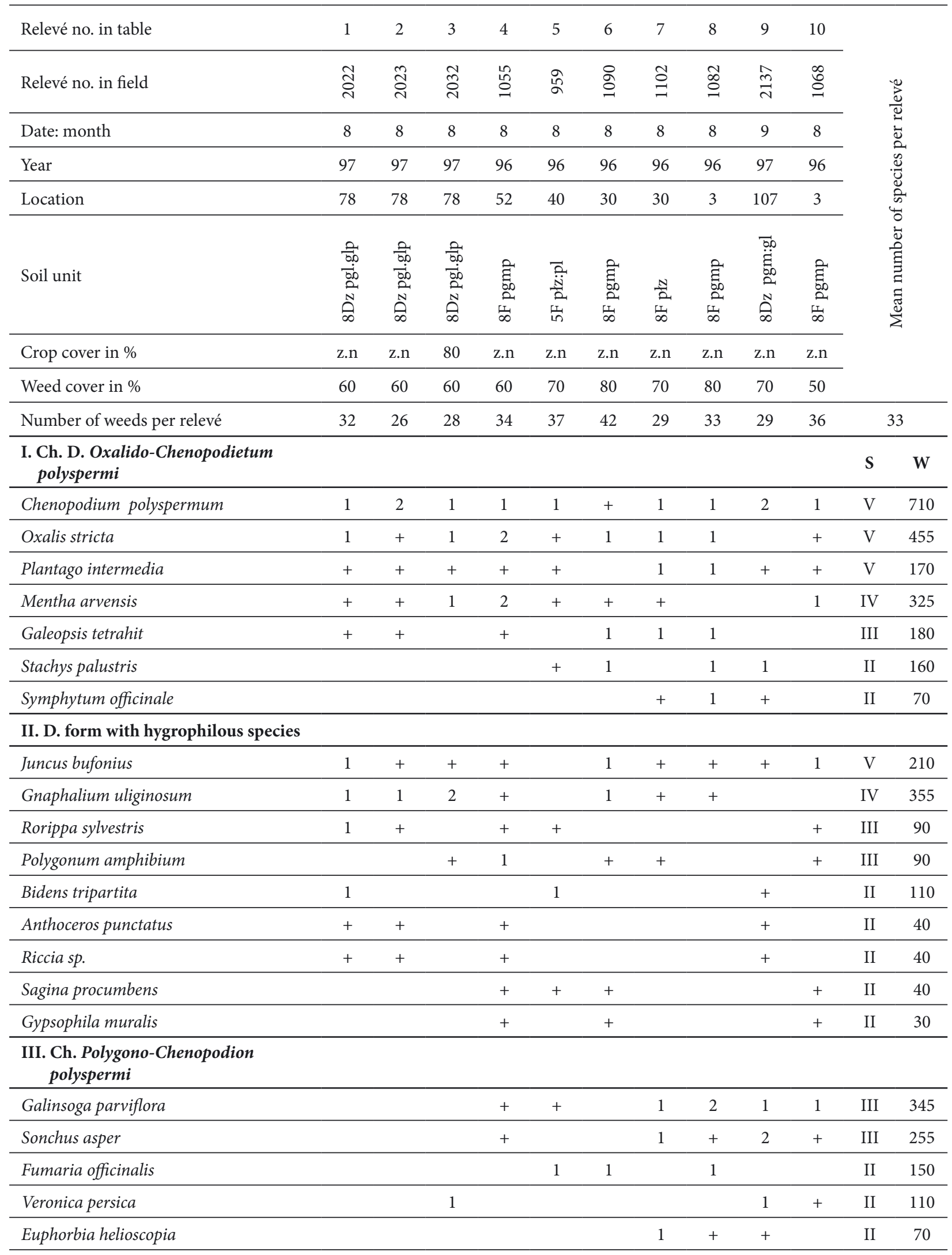


cd. Table 5

\begin{tabular}{|c|c|c|c|c|c|c|c|c|c|c|c|c|}
\hline Lamium purpureum & & & + & & & & 1 & & & + & II & 70 \\
\hline \multicolumn{13}{|c|}{$\begin{array}{l}\text { IV. Ch. D. Panico-Setarion, Polygono- } \\
\text { Chenopodietalia }\end{array}$} \\
\hline Chenopodium album & 1 & 1 & 1 & 1 & + & 2 & & 2 & 1 & 1 & $\mathrm{~V}$ & 660 \\
\hline Stellaria media & + & + & 1 & 2 & 1 & 1 & 1 & 1 & + & 1 & $\mathrm{~V}$ & 505 \\
\hline Echinochloa crus-galli & + & 1 & + & + & + & 1 & 1 & + & & + & $\mathrm{V}$ & 210 \\
\hline Matricaria maritima ssp. inodora & 2 & 2 & 2 & + & + & + & & & + & + & IV & 575 \\
\hline Raphanus raphanistrum & & & & & & + & & 1 & & 1 & II & 110 \\
\hline Sonchus arvensis & & & + & & + & & & + & & + & II & 40 \\
\hline \multicolumn{13}{|l|}{ V. Ch. Stellarietea mediae } \\
\hline Myosotis arvensis & & 1 & + & + & & + & & + & + & + & IV & 110 \\
\hline Fallopia convolvulus & + & + & & & + & 1 & & + & & & III & 90 \\
\hline Vicia tetrasperma & + & & + & + & & + & & + & & & III & 50 \\
\hline Sinapis arvensis & & & & + & 3 & 2 & & 1 & & & II & 610 \\
\hline Chaenorhinum minus & & & & & + & 1 & & + & & + & II & 80 \\
\hline Viola arvensis & + & + & + & & + & & & & & 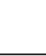 & II & 40 \\
\hline Vicia hirsuta & + & & + & & & + & & & & + & II & 40 \\
\hline Capsella bursa-pastoris & & & & + & & & + & + & & + & II & 40 \\
\hline Anagallis arvensis & & & + & & + & & & & + & + & II & 40 \\
\hline Rumex crispus & + & & & & & + & & + & & & II & 30 \\
\hline Polygonum aviculare & & & + & & & & & + & & + & II & 30 \\
\hline \multicolumn{13}{|l|}{ VI. Accompanying species } \\
\hline Erysimum cheiranthoides & + & + & & 1 & + & 1 & 1 & 1 & + & + & $\mathrm{V}$ & 250 \\
\hline $\begin{array}{l}\text { Polygonum lapathifolium ssp. } \\
\text { lapathifolium }\end{array}$ & 1 & 1 & + & & + & + & 1 & 2 & & + & IV & 365 \\
\hline Artemisia vulgaris & 1 & + & & & + & + & + & + & + & & IV & 110 \\
\hline Plantago major & + & & & + & + & + & + & + & & + & IV & 70 \\
\hline Galeopsis bifida & + & & & + & & 1 & 1 & + & & + & III & 140 \\
\hline Polygonum persicaria & & & + & 1 & + & + & + & & & + & III & 100 \\
\hline Equisetum arvense & & & 1 & + & + & & & & + & + & III & 90 \\
\hline Veronica arvensis & + & + & + & + & & & + & + & & & III & 60 \\
\hline Galium aparine & + & + & & & & + & & + & & & II & 40 \\
\hline Cirsium arvense & + & + & & & & + & & & + & & II & 40 \\
\hline Trifolium repens & + & + & & & & & & & + & & II & 30 \\
\hline Cardaminopsis arenosa & + & & & & + & & & + & & & II & 30 \\
\hline
\end{tabular}

Sporadic species: I - Lapsana communis 9(+); II - Polygonum hydropiper 1(1), 2(1); Potentilla anserina 5(1), 9(1); Myosurus minimus 4(+); Rorippa palustris 5(+); Ranunculus repens 5(+); Cerastium holosteoides 6(+); Spergularia rubra 9(+); III - Veronica agrestis 3(+), 9(+); Veronica polita 9(1); Lamium amplexicaule 6(+); Sonchus oleraceus 7(+); IV - Atriplex patula 5(1), 10(+); Setaria viridis 5(+), 6(+); Setaria pumila 6(+); Solanum nigrum 3(+); V - Melandrium noctiflorum 3(+), 4(+); Thlaspi arvense 3(+), 6(+); Papaver argemone 4(+), 6(+); Anthemis arvensis 5(+); Vicia angustifolia 6(+), 10(+); Centaurea cyanus 6(+); Vicia villosa 6(+); Papaver dubium 6(+); Galeopsis speciosa 7(+); VI - Arenaria serpyllifolia 1(+), 2(+); Sinapis alba 6(+), 10(+); Agropyron repens 6(+), 10(1); Amaranthus retroflexus 7(+), 9(2); Urtica urens 4(+); Lythrum salicaria 4(+); Glechoma hederacea 5(1); Linaria vulgaris 5(+); Plantago lanceolata 5(r); Erodium cicutarium 5(+); Medicago lupulina 5(+); Chamomilla suaveolens 7(+); Galium spurium 7(+); Malva neglecta 7(+); Convolvulus arvensis 9(+); Taraxacum officinale 9(+).

Comments: numbers after species names inform about the relevé number in the table, z.n - withered top leaves 
Table 6

Galinsogo-Setarietum ( R.Tx. et Beck. 1942) R.Tx.1950

Subassociation

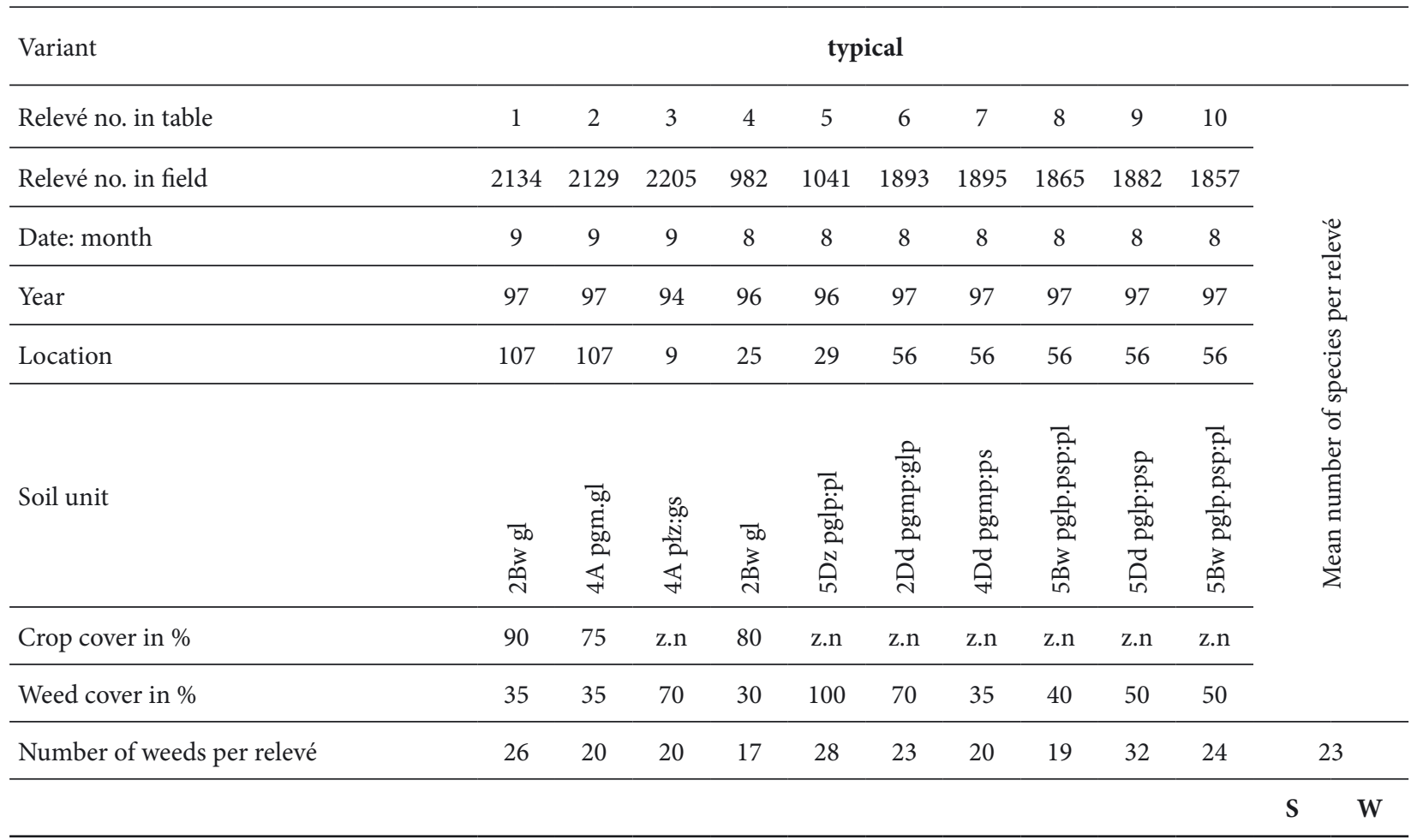

I. Ch. D. Galinsogo-Setarietum

\begin{tabular}{|c|c|c|c|c|c|c|c|c|c|c|c|c|}
\hline Galinsoga parviflora & 1 & 1 & 3 & 2 & 3 & 2 & 2 & 1 & 1 & 1 & $\mathrm{~V}$ & 1525 \\
\hline Setaria pumila & + & & + & + & & 1 & + & & 1 & + & IV & 150 \\
\hline Galinsoga ciliata & 1 & 2 & & 1 & + & 1 & & + & & + & IV & 355 \\
\hline
\end{tabular}

\section{Ch. Polygono-Chenopodion}

\begin{tabular}{|c|c|c|c|c|c|c|c|c|c|c|c|c|}
\hline Veronica persica & 1 & 1 & 1 & & & 2 & + & 1 & + & + & IV & 405 \\
\hline Lamium purpureum & + & + & + & & & 1 & + & + & & 1 & IV & 150 \\
\hline Veronica polita & + & + & & & & & + & & + & + & III & 50 \\
\hline Euphorbia helioscopia & 1 & & & 1 & 1 & + & + & & + & & III & 180 \\
\hline Sonchus asper & 1 & 1 & & & & & & & 1 & & II & 150 \\
\hline Lamium amplexicaule & & & & & & & + & + & & 1 & II & 70 \\
\hline Veronica agrestis & & + & & + & & + & 1 & 1 & 1 & + & IV & 190 \\
\hline Sonchus oleraceus & & + & & & & + & 1 & + & & & II & 80 \\
\hline Fumaria officinalis & & & & & & & + & 1 & 1 & & II & 110 \\
\hline
\end{tabular}

III. Ch.D. Panico-Setarion,

Polygono-Chenopodietalia

Chenopodium album 
cd. Table 6

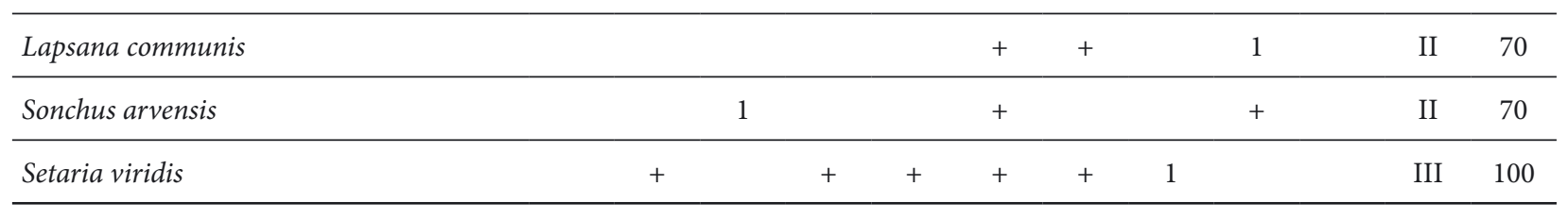

IV. Ch.Stellarietea mediae

\begin{tabular}{|c|c|c|c|c|c|c|c|c|c|c|c|c|}
\hline Stellaria media & & + & 1 & 1 & 1 & 2 & 1 & & 2 & 2 & IV & 735 \\
\hline Capsella bursa-pastoris & + & + & & & + & & + & + & + & + & IV & 70 \\
\hline Myosotis arvensis & + & & + & & & & & + & + & + & III & 50 \\
\hline Anagallis arvensis & & + & & + & & & + & + & & & II & 40 \\
\hline Fallopia convolvulus & & & & & + & + & & + & + & & II & 40 \\
\hline Anthemis arvensis & & & + & & & & & & + & + & II & 30 \\
\hline Vicia tetrasperma & & & + & + & & & & & + & & II & 30 \\
\hline Vicia hirsuta & & & & + & & + & & & & + & II & 30 \\
\hline
\end{tabular}

V. Accompanying species

\begin{tabular}{|c|c|c|c|c|c|c|c|c|c|c|c|}
\hline Galium aparine & 1 & & & & & & 1 & + & & II & 110 \\
\hline Equisetum arvense & + & & + & & & + & & 1 & + & III & 90 \\
\hline Erodium cicutarium & & & & + & & + & & + & & II & 30 \\
\hline Convolvulus arvensis & + & & 2 & + & + & & & & 1 & III & 255 \\
\hline Armoracia rusticana & & & & + & 1 & & & + & & II & 70 \\
\hline Polygonum lapathifolium ssp. lapathifolium & & & & + & 1 & & & + & & II & 70 \\
\hline Melandrium album & & & + & + & + & & & & & II & 30 \\
\hline Erysimum cheiranthoides & + & & & 1 & & & 1 & + & 1 & III & 170 \\
\hline Cirsium arvense & + & + & + & + & & & & + & 1 & III & 100 \\
\hline Artemisia vulgaris & & & + & + & & + & & 1 & & II & 80 \\
\hline Polygonum persicaria & + & & & & + & & & & + & II & 30 \\
\hline Agropyron repens & & & + & + & & & & + & & II & 30 \\
\hline Amaranthus retroflexus & + & & & 1 & & & 1 & & & II & 110 \\
\hline
\end{tabular}

Sporadic species: II - Chenopodium polyspermum 1(1), 2(1); III - Echinochloa crus-galli 2(+), 4(+); Raphanus raphanistrum 5(+), 10(+); Geranium pusillum 3(+); Polygonum lapathifolium ssp. pallidum 4(+); Matricaria maritima ssp. inodora 4(+); IV - Papaver rhoeas 1(+), $4(+)$; Viola arvensis 1(+), 8(+); Anchusa arvensis 5(+), 9(+); Sinapis arvensis 1(+); Melandrium noctiflorum 5(+); Vicia villosa 5(+); Conyza canadensis 5(+); Polygonum aviculare 7(+); Arabidopsis thaliana 9(+); Thlaspi arvense 9(+); Vicia angustifolia 9(+); Avena fatua $9(\mathrm{r})$; V - Arenaria serpyllifolia 1(+), 3(+); Taraxacum officinale 3(+), 5(+); Veronica arvensis 3(+), 8(+); Medicago lupulina 4(+), 6(+); Galeopsis bifida 5(1), 10(+); Galium spurium 6(+), 9(+); Urtica urens 1(+); Leucanthemum vulgare 1(+); Tussilago farfara 1(+); Amaranthus hybridus 2(1); Trifolium repens 2(+); Poa annua 2(+); Rorippa sylvestris 2(+); Melilotus officinalis 4(+); Malva sylvestris 5(+); Malva neglecta 5(+); Potentilla anserina 5(+); Elsholzia ciliata 6(+); Mentha arvensis 10(+); Plantago major 10(+); Ballota nigra 10(r).

Comments: numbers after species names inform about the relevé number in the table, z.n - withered top leaves 


\section{DISCUSSION}

In root crops, on compact soils of the Podlaski Przełom Bugu mesoregion, there were observed plots of communities classified as Polygono-Chenopodion polyspermi. This calciphilous alliance is represented by: Lamio-Veronicetum politae, Oxalido-Chenopodietum polyspermi and Galinsogo-Setarietum. Little plots of these phytocoenoses were rarely observed in the investigated area. It is a result of a little proportion of wheat soil complexes, abundant in nutrients and $\mathrm{CaCO}_{3}$, in that area. More often, plots of intermediate communities between Panico-Setarion and PolygonoChenopodion polyspermi alliances as well as communities of the Panico-Setarion alliance are observed in root crops of the study area.

The thermophilous and caliciphilous association Lamio-Veronicetum politae was usually noted on typical black and deluvial soils. These phytocoenoses are floristically rich, but poorer than similar associations reported in other regions of Poland, e.g. Kraków Jurassic area (K o r n a ś, 1950), Opole region (M ichalak, 1972), Częstochowa Upland (Wnuk, 1989). The most characteristic species: Veronica polita, Veronica agrestis and Veronica opaca, are considered to be rare in many regions of Poland (W a rcholińska, 1998; Szmeja, 1998; K o r c z y ń s k i, 1998). The first two mentioned species were relatively frequently noted in the Podlaski Przełom Bugu mesoregion, whereas Veronica opaca was more rarely observed. The identified phytocoenoses represent a northern Polish variety of the association, with a large proportion of Veronica agrestis and only a small participation of typical calciphilous species from the Caucalidion lappulae alliance (Wnuk, 1987). Only a few species from that group were recorded: Melandrium noctiflorum, Avena fatua, Aethusa cynapium. On the other hand, Veronica polita - a species typical for the south-central Polish variant - was noted frequently and abundantly.

Plots of Oxalido-Chenopodietum polyspermi were also rarely observed. Typical phytocoenoses of the association used to develop on fertile and wet alluvial soils along the large rivers (A n i o $1-\mathrm{K}$ w i a t k ow s ka, 1990; Wó j cik, 1998, 2001; Mat u s zkie w i c z , 2001). In the area of the Podlaski Przełom Bugu mesoregion, the association was also noted on black soils in the Bug river valley and along its tributaries. The phytocoenoses are floristically rich (on average 33 species), richer than those investigated by W ó j c i k (1998) in the Przemyśl Foothills and W ę g r z y n e k (2006) in the Silesian Upland and poorer than the communities described by W ó j c i k (1980) from the middle Vistula river valley. The phytocoenoses recorded in the area of the Podlaski Przełom Bugu mesoregion are similar in floristic composition to the communities described by Wójcik (2001) from the Polish
Lowlands. A little proportion of species characteristic for Panico-Setarion, with the exception of Echinochloa crus-galli, is characteristic for them. Symphytum officinale - a distinguishable species for the association in the river valleys of the southern Poland - was also recorded rarely (W ó j c i k, 2001).

Typical plots of Galinsogo-Setarietum were noted only in the vicinity of farms in the area of the Podlaski Przełom Bugu mesoregion. They were floristically the poorest phytocoenoses on compact soils; however, cover weed was very high. These communites were species richer than these reported by $\mathrm{W}$ a r c holin $\mathrm{s} \mathrm{ka}$ (1987) and Aniol-Kwiatkowska (1990), but floristically poorer than the association distinguished in the Silesian Upland by Węgrzynek (2006). Similarly as in other regions of Poland, Galinsoga parviflora was the dominant species in the studied phytocoenoses. Due to a large similarity of these phytocoenoses to Echinochloo-Setarietum, a group of authors question the phytosociological distinctiveness of the association, including it in the ruderal variant of Echinochloo-Setarietum (S i c i ń s k i, 2003).

Intermediate plots between Panico-Setarion and Polygono-Chenopodion polyspermi were frequently observed in the area of the Podlaski Przełom Bugu mesoregion. These phytocoenoses were distinguishable by the mass occurrence of Echinochloa crus-galli and the presence of a group of species characteristic for the Polygono-Chenopodion polyspermi alliance, e.g. Euphorbia helioscopia, Sonchus asper, Veronica agrestis. Intermediate phytocoenoses developing in root crops were rarely described, e.g. by K o r n a ś (1950) from the Kraków Jurassic area, K o z a k (2002) from the Woźniki-Wieluń Upland, Skrajna and S k r z y c z y ń s k a (2008) from the Kałuszyn Upland. Phytocoenoses of Echinochloo-Setarietum typicum - subvariant with Veronica persica (Panico-Setarion alliance) with a large proportion of species characteristic for the Polygono-Chenopodion polyspermi alliance - were also frequently noted. In floristic composition, they were similar to Echinochloo-Setarietum veronicetosum persicae described from the Przemyśl Foothills by Wójcik (1998), however they differ in the absence of neutro- and basophilous species characteristic for cereal associations (Lathyrus tuberosus, Avena fatua, Papaver rhoeas), and numerous occurrence of Lamium purpureum.

\section{REFERENCES}

Anioł-Kwiatkowska J., 1990. Zbiorowiska segetalne Wału Trzebnickiego. Florystyczno-ekologiczne studium porównawcze. / Segetal communities of the Trzebnica Moraine Belt. A floristic and ecological comparative study. Wyd. Univ. Wrocław. Prace Bot.: 46-230. 
K o r c z y ń s k i M., 1998. Przemiany i stan flory segetalnej Bydgoszczy. / Bydgoszcz segetal flora changes and state. Acta Univ. Lodz., Folia Bot. 13: 65-72.

Kornaś J., 1950. Zespoły roślinne Jury Krakowskiej. Cz. I. Zespoły pól uprawnych. / Plant associations of the Kraków Jurassic area. Part 1. Associations of cultivated fields. Acta Soc. Bot. Pol. 20 (2): 361-438.

K o z a k M., 2002: Zbiorowiska segetalne gminy Rudnik (województwo opolskie). / Segetal communities of the gmina (commune) of Rudnik (Opolskie Voivodship (region). Fragm. Flor. Geobot. Polon. 9: 219-272.

Matuszkiewicz W., 2001. Przewodnik do oznaczania zbiorowisk roślinnych Polski. Wyd. Nauk. Państwowe Wydawnictwo Naukowe, Warszawa: 1-537.

Michalak S., 1972. Zbiorowiska polne Opola i okolicy. / Field communities of Opole and its surroundings. Opol. Rocz. Muz. 5: 309-320.

Rzymowska Z., Skrzyczyńska J., 2006 a. Zbiorowiska roślinne pól uprawnych Podlaskiego Przełomu Bugu. Cz. II. Zbiorowiska zbożowe. / Plant communities of cultivated fields of the Podlaski Przełom Bugu mesoregion. Part 2. Cereals communities. Acta Agrobot. 59 (2): 377-391.

Rzymowska Z., Skrzyczyńska J., 2006 b. Zbiorowiska roślinne pól uprawnych Podlaskiego Przełomu Bugu. Cz. III. Zbiorowiska ścierniskowe gleb piaskowych. / Plant communities of cultivated fields of the Podlaski Przełom Bugu mesoregion. Part 3. Stubble field communities on sandy soils. Acta Agrobot. 59 (2): 393-419.

Rzymowska Z., Skrzyczyńska J., 2006 c. Zbiorowiska roślinne pól uprawnych Podlaskiego Przełomu Bugu. Cz. IV. Zbiorowiska ścierniskowe gleb zwięzłych. Plant communities of the cultivated fields of the Podlaski Przełom Bugu mesoregion. Part 4. Stubble field communities of compact soils. Acta Agrobot. 59 (2): 421-440.

Rzymowska Z., Skrzyczyńska J., 2007. Plant communities of cultivated fields of the Podlaski Przełom Bugu mesoregion. Part 5. Root crop communities of light soils. Acta Agrobot. 60 (1): 191-205.

S i c i ń s k i J. T., 2003. Agrofitocenozy dorzecza środkowej Warty i Bzury - stan, dynamika i zagrożenia. / Agrophytocoenoses of the middle Warta and Bzura rivers basin - the state, dynamics and threats. Wyd. Uniw. Łódź.: 1-55.

Skrajna T., Skrzyczyń ska J., 2008. Plant communities and associations of root crops of the Kałuszyn Upland. Acta Agrobot. 61 (2): 239-249.

Skrzyczyńska J., Rzymowska Z., 2005. Zbiorowiska roślinne pól uprawnych Podlaskiego Przełomu Bugu. Cz. I. Zespoły zbożowe. / Plant communities of cultivated fields of the Podlaski Przełom Bugu mesoregion. Part 1. Cereal communities. Acta Agrobot. 58 (1): 255-290.

S z m e ja K., 1998. Rzadkie i zagrożone wyginięciem chwasty upraw polnych Wzniesień Elbląskich, Doliny Dolnej
Wisły i Równiny Charzykowskiej. / Rare and threatened weed species of field crops of the Elbląg Elevations, Lower Vistula valley and Charzykowy Plain. Acta Univ. Lodz., Folia Bot. 13: 37-42.

Warcholińska A. U., 1987. Zbiorowiska segetalne Wzgórz Radomszczańskich. / Segetal communities of the Radomsko Hills. Bad. Fizjogr. Pol. Zach., Ser. B, 38: 123-153.

Warcholińska A. U., 1998. Właściwości zagrożonych segetalnych roślin naczyniowych Polski. / Features of threatened segetal vascular plants in Poland. Acta Univ. Lodz., Folia Bot. 13: 7-14.

Węgrzynek B., 2006: Roślinność segetalna Wyżyny Śląskiej. Cz. V. Zbiorowiska chwastów upraw okopowych ze związku Eu-Polygono-Chenopodion polyspermi (Koch 1926) Siss. 1946. / Segetal vegetation of the Silesian Upland. Part V. Root crop weed communities of the Eu-Polygono-Chenopodion polyspermi (Koch 1946) Siss. 1946 alliance. Weed communities of maize crops. Natura Silesiae Superioris, Centrum Dziedzictwa Przyrody Górnego Śląska, 9 (2005): 63-83.

Wnuk Z., 1987. Zespół Lamio-Veronicetum politae Kornaś 1950 w Polsce. / The Lamio-Veronicetum politae Kornaś 1950 association in Poland. Zesz. Nauk. AR w Krakowie, 216 (19): 95-136.

W nu k Z., 1989. Zbiorowiska segetalne Wyżyny Częstochowskiej na tle zbiorowisk segetalnych Polski. / Segetal communities of the Częstochowa Upland against the background of Poland`s segetal communities. Monogr. Bot. 71: 1-118.

Wójcik Z., 1980. Plant communities of Mazovian cultivated fields. III. Root-crop communities. Pol. Ecol. Stud. 6 (3): 545-569.

Wójcik Z., 1998. Zbiorowiska segetalne Pogórza Przemyskiego i jego najbliższego otoczenia. / Segetal communities of the Przemyśl Foothills and their immediate neighbourhood. Fragm. Flor. Geobot. Ser. Polonica, Kraków, 5: 117-164.

Wójcik Z., 2001. Oxalido-Chenopodietum polyspermi Sissingh 1942 - zespół chwastów upraw okopowych dolin rzecznych i pogórzy w Polsce. / The Oxalido-Chenopodietum polyspermi Sissingh 1942 - association of root crop weeds in river valleys and foothills of Poland. Prace Geogr. 178: 87-117.

\section{Zbiorowiska roślinne pól uprawnych Podlaskiego Przełomu Bugu Cz. VI. Zbiorowiska upraw okopowych gleb zwięzłych}

\section{Streszczenie}

Praca obejmuje analizę zbiorowisk upraw okopowych wykształcających się na glebach zwięzłych. Jest to kolejna część charakterystyki zbiorowisk Podlaskiego Przełomu Bugu. Badane fitocenozy 
wyróżniono na podstawie 103 zdjęć fitosocjologicznych wykonanych metodą Braun-Blanquet'a. W analizowanych siedliskach spotykano płaty zespołów ze związku Polygono-Chenopodion polyspermi: Lamio-Veronicetum politae, Galinsogo-Setarietum i Oxalido-Chenopodietum polyspermi. Lamio-Veronicetum i Oxalido-Chenopodietum. Są to zbiorowiska notowane rzadko i na niewielkich powierzchniach na badanym terenie ze względu na niewielki udział odpowiednich siedlisk. Oxalido-Chenopodietum na terenie Podlaskiego Przełomu Bugu wykształcał się w dolinach cieków wodnych na żyznych madach i równie często na czarnych ziemiach. Typowe płaty Galinsogo-Setarietum z masowym występowaniem Galinsoga parviflora spotykano jedynie w pobliżu zabudowań wiejskich. Dość często natomiast w uprawach okopowych na glebach zwięzłych wykształcały się płaty zbiorowisk pośrednich między związkami Panico-Setarion i Polygono-Chenopodion polyspermi oraz Echinochloo-Setarietum typicum w podwariancie z Veronica persica i Echinochloo-Setarietum fumarietosum. 
